\title{
ARTICLE \\ Local scale variation in the reproductive pattern of the southern geoduck, Panopea abbreviata (Bivalvia: Hiatellidae), in Patagonia
}

\author{
Variación en el patrón reproductivo a escala local de la almeja panopea, \\ Panopea abbreviata (Bivalvia: Hiatellidae), en Patagonia \\ Paula C. Zaidman ${ }^{1,3}$, Marina A. Kroeck ${ }^{1}$, Silvina Van der Molen ${ }^{2,3}$, \\ Gabriela Williams $^{2,3}$, Leilen Gracia-Villalobos ${ }^{2,3}$, Erica \\ Oehrens-Kissner $^{1}$ and Enrique M. Morsan ${ }^{1}$
}

\begin{abstract}
${ }^{1}$ Centro de Investigación Aplicada y Transferencia Tecnológica en Recursos Marinos Alte. Storni (CIMAS), Universidad Nacional del Comahue, Provincia de Río Negro, CONICET Guemes 1030, San Antonio Oeste, Rio Negro, Argentina ${ }^{2}$ Centro para el Estudio de Sistemas Marinos, CONICET, Boulevard Brown 2850 (U9120ACV), Puerto Madryn, Chubut, Argentina ${ }^{3}$ Consejo Nacional de Investigaciones Científicas y Técnicas (CONICET), Av. Rivadavia 1917, (C1033AAJ) CABA, Argentina. *Corresponding author: paulazaidman@ibmpas.org
\end{abstract}

\begin{abstract}
Resumen.- Durante el 2007 se realizaron estudios para explorar la variabilidad espacial a escala local, del ciclo reproductivo de Panopea abbreviata en 3 poblaciones presentes en los golfos Nord-patagónicos (El Sótano y Puerto Lobos, en el Golfo San Matías, y Punta Conos en el Golfo San José), Argentina. Estudios previos determinaron que P. abbreviata presenta un patrón reproductivo, en ambos sexos, caracterizado por una continua proliferación y evacuación de gametos durante todo el año. Sin embargo, el uso de indicadores cuantitativos (distribución de frecuencia de diámetros ovocitarios, ovocitos por campo ocular y área ovocitaria relativa) para las hembras permitió observar una ligera estacionalidad. Las variaciones en el ciclo reproductivo fueron relacionadas con el régimen anual de temperatura de cada sitio. Las hembras de El Sótano y Puerto Lobos muestran una estacionalidad similar en el patrón reproductivo: las fases de proliferación y maduración predominan cuando la temperatura disminuye durante otoño (marzo-mayo); este patrón se revierte, cuando las temperaturas comienzan a aumentar durante primavera (septiembre-noviembre). Mientras que, en Punta Conos este patrón es más irregular. Sin embargo, en todas las poblaciones se encontraron individuos de ambos sexos en estadio de madurez durante todo el año, evidenciando la ausencia de un periodo de inactividad gonadal. En las 3 poblaciones ambos sexos se caracterizan por múltiples pulsos cortos de evacuación de gametos. Este mismo patrón se encontró en otras poblaciones de P. abbreviata y es único para el genero Panopea. Los 3 sitios estudiados presentaron un patrón reproductivo similar.
\end{abstract}

Palabras clave: Almeja panopea, Panopea abbreviata, gametogénesis, ciclo reproductivo, Patagonia

\begin{abstract}
During 2007 was carried out studies to explore local scale spatial variability in the reproductive cycle of Panopea abbreviata in 3 sites of the northern Patagonian gulfs (El Sótano and Puerto Lobos, in San Matías Gulf, and Punta Conos in San José Gulf), Argentina. Previous reports have revealed that P. abbreviata exhibits a reproductive pattern characterized, in both sexes, by continuous proliferation of gametes and spawning throughout the year. However, the use of quantitative indicators for females has shown a slight seasonality to this pattern. Local spatial variability in the reproductive cycle of P. abbreviata was observed at 3 sites and related to variation in the annual temperature regime at each locality. The females of El Sótano and Puerto Lobos showed similar seasonality in the reproductive pattern: proliferation and maturation phases prevailed over spawning stages when temperature decreased during autumn (March-May); this pattern was reversed when temperatures began to increase during spring (September-November). At Punta Conos this pattern is more irregular. However, at all localities, mature individuals of both sexes were present throughout the year, without a resting period during the reproductive cycle. The reproductive pattern is similar in the 3 sites with many small pulses in reproductive activity that are difficult to detect and characterized by year-round spawning. The same pattern was found in other localities of $P$. abbreviata and is unique in the genus Panopea.
\end{abstract}

Key words: Geoduck, Panopea abbreviata, gametogenesis, reproductive cycle, North Patagonia 


\section{INTRODUCTION}

Coordination between the events of gametogenesis, such as initiation or the onset of spawning, and changes in the external environment determined the pattern of the reproductive cycle of marine invertebrates (Sastry 1977, Olive 1994, Hooker \& Creese 1995). Most marine invertebrates have seasonal reproductive cycles with highly synchronized patterns of spawning (Olive et al. 2000). The annual reproductive cycle of bivalves commonly involves a period of gametogenesis followed by spawning events, which in turn is followed by a period of gonad reconstitution. The timing and duration of each stage of gametogenesis vary within and between species (Gosling 2003, Matias et al. 2013). Many bivalves have a short period of spawning, which concentrates reproductive output. Other species have an extended period of spawning, which hold out several months. Both patterns of spawning are adaptations to different environments (Joaquim et al. 2014). At predictable environments, shorter period of spawning increase the probability of high reproductive success; but at inconstant and unpredictable environments, long period of spawning increase the probability that almost any portion of the reproductive investment is successful (Calvo et al. 1998).

Regardless of geographical area, similar environmental factors - in particular temperature and food availability-regulate the reproduction in coastal marine bivalves (Olive 1994, Joll \& Caputti 1995, Freites et al. 2010). Temperature is usually considered a major determinant that defines the annual spawning period (Eversole 1989). Besides the direct effects of temperature on reproductive physiology, temperature also modulates the cycles of plankton and other environmental variables (Newell et al. 1982).

For the genus Panopea, several studies have examined the relationship between temperature cycle and gametogenic development. For Panopea generosa, of Southern British Columbia, and P. zelandica, of northern New Zealand, gametogenic development starts during late autumn and winter when the water temperature is low; gametogenic development continues in late winter and spawning occurs in spring and early summer as water temperature increases (Sloan \& Robinson 1984, Gribben et al. 2004). The inverse pattern was observed for P. globosa, of Upper Gulf of California (Calderón-Aguilera et al. 2010). In this sub-tropical species, gametogenic development starts in mid-fall and spawning occurs during the coldest period of the year. The gametogenic development of the southern geoduck ( $P$. abbreviata) is characterized by continuous gamete proliferation and spawning throughout the year (Van der Molen et al. 2007, Zaidman et al. 2012). In El Sótano (NW-San Matías Gulf) quantitative indicators for female geoducks have shown slight seasonality in this pattern. Gamete proliferation and maturation phases prevailed when temperatures decrease during autumn and decreased when temperatures began to increase during spring (Zaidman et al. 2012). The use of quantitative indicators of the reproductive cycle in other site will allow study whether the seasonality observed in El Sótano occurs in other populations of the specie.

Panopea abbreviata Valenciennes, 1839 is an endemic species found only in the SW Atlantic region (Ageitos de Castellanos 1967). It lives deeply buried in sand and mud substrates to a depth of $40 \mathrm{~cm}$, and is especially abundant in the San Matías and San José Gulfs. Panopea abbreviata has a spatial distribution characterized by disjoint subpopulations parallel to the coastline in shallow waters to depths of $75 \mathrm{~m}$. A fishery for southern geoduck in North Patagonia has developed under an experimental status since 1999 in two beds located in the San Matías Gulf (SMG): El Sótano(NW) and Puerto Lobos (SW). During the first year of exploitation, geoduck landings totaled $5.7 \mathrm{t}$. while in subsequent years total landings have varied between 1.8 and $15.6 \mathrm{t}$ (Morsan et al. 2010).

The purpose of this study was to explore local scale variation in the reproductive cycle of $P$. abbreviata at 3 localities on the northern Patagonian coast, and to relate qualitative and quantitative reproductive indicators with the annual thermal cycles for each locality.

\section{MATERIALS AND METHODS}

\section{SAMPLing}

Samples were collected monthly during 2007 from subtidal sand beds at 5-25 m depth at 3 localities in northern Patagonia (Fig. 1): El Sótano, on the northwest coast of the SMG (4057'S $65^{\circ} 06^{\prime} \mathrm{W}$ ); Puerto Lobos, on the southwest coast of the SMG ( $\left.42^{\circ} 00^{\prime} \mathrm{S}-65^{\circ} 04^{\prime} \mathrm{W}\right)$ and, Punta Conos, on the southwest coast of the San José Gulf (SJG) (42² $\left.21^{\prime} S-64^{\circ} 33^{\prime} \mathrm{W}\right)$. Each sample consisted of extracting approximately 30 clams from the substrate by SCUBA using a pump driven water stinger. Clams were taken to the laboratory, where soft portions were removed. Soft parts and valves were drained of water and weighed. Shell length ( $\mathrm{Lt}$ ) was measured between the anterior and posterior margins of the shell using vernier calipers $( \pm 0.01 \mathrm{~mm})$.

A transverse section of the visceral mass was dissected and fixed in Davidson solution for $24 \mathrm{~h}\left(4^{\circ} \mathrm{C}\right)$, and subsequently preserved in $70 \%$ ethanol. For histological analysis, gonad samples were dehydrated in an ethanol series and embedded in paraffin wax. Sections 5-7 $\mu \mathrm{m}$ thick were cut and stained 


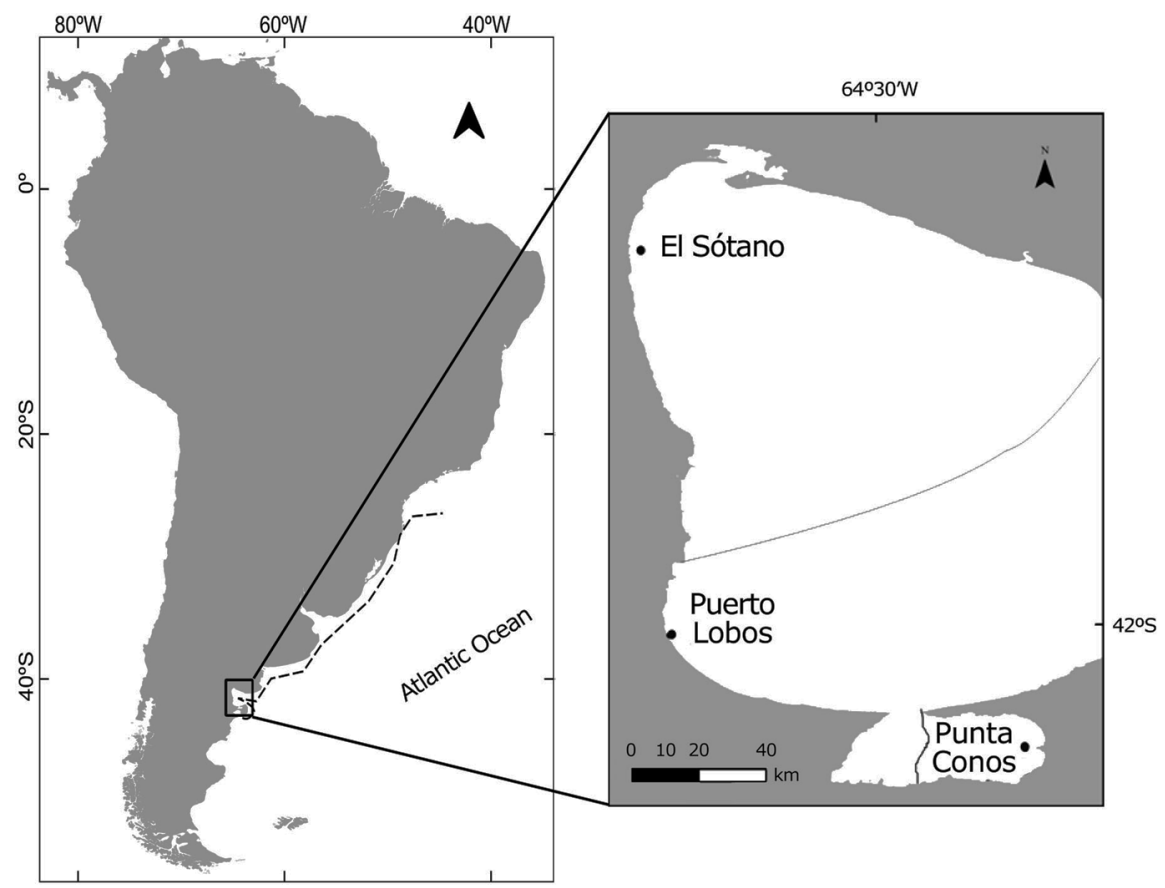

Figure 1. Left: Map of America del Sur, the dotted line shows the distribution of the southern geoduck, Panopea abbreviata, and the square shows the sampling area. Right: Sampling sites/ Izquierda: Mapa de América del Sur, la línea punteada muestra la distribución de la almeja panopea, Panopea abbreviata, y el cuadrado el área de muestreo. Derecha: Sitios de muestreo

with Harris's haematoxylin-eosin. Each histological section was examined under light microscope at 100x magnifications, to determine gonadal stages.

\section{TEMPERATURE DATA ACQUISITION AND ANALYSIS}

Sea surface temperature (SST) was calculated through a method based on the 'Split Window Technique' algorithm (McClain et al. 1985). Daily maps of SST were composed using up to 5 different NOAA acquisitions. Data for monthly SST for each site was produced by averaging the temperature at a window of $3 \times 3$ pixels centered at the location of each site.

Satellite data and in situ records from El Sotano were compared to evaluate the relationships between both sources of temperature data. In situ temperature records were obtained with a temperature data-loggers (Optic Stow Away-Temp $\left({ }^{\circ} \mathrm{C}\right.$ ) ONSET, $\left( \pm 0.20^{\circ} \mathrm{C}\right)$ with data taken every $6 \mathrm{~h}$ at a depth of 10 $\mathrm{m}$ from El Sótano (September, 7 2007-August, 26 2008), at $2.5 \mathrm{~km}$ distance from the coast. Daily average in situ temperature from El Sótano was calculated and matched with daily data from NOAA-AVHRR. A total of 363 scenes of SST were processed using Erdas Imagine 8.7.

The relationship between in situ temperature and AVHRR derived SST was analyzed through linear regression analyses. Bias, slope and the determination coefficient $\left(\mathrm{r}_{\text {SMA }}^{2}\right)$ were calculated following a type II linear regression model, Standard Major Axis (SMA) (McArdle 1988, Sokal \& Rohlf 1995).

SMA techniques provide a better estimate of the relationship between two variables than that provided by ordinary linear regression, because the residual variance is minimized in both $x$ and $y$ dimensions, rather than in the $y$ dimension only (Sokal \& Rohlf 1995). The statistical analyses were carried out using (S) MATR software (version 1$)^{1}$. The coefficient of determination indicates the overall degree of linear association between in situ and satellite estimates (proportion of the variance explained by a statistical model), but it is not a measure of the algorithm performance. Thus, the slope (closer to 1), the intercept (closer to 0 ) and the above-mentioned statistics are used to evaluate the comparison between MCSST algorithms and the in situ records. 


\section{Sexual Categories and gonadal STAGes}

The sexual categories were determined as follows:

1.- Undifferentiated: most of the gonad is made up of connective tissue, with few and small follicles filled with primordial germ cells. These individuals cannot be sexed

2.- Males: follicles have spermatogonia, spermatocytes or spermatozoa

\section{3.- Females: follicles have oogonia or oocytes}

4.- Hermaphrodites: follicles have both female and male gametes

Gonadal stages were critically evaluated based on an adaptation of the maturity scale described by Zaidman et al. (2012).

The histological features for the different stages of the gonadic cycle are depicted in Figs. 2 and 3 and defined in Table 1.

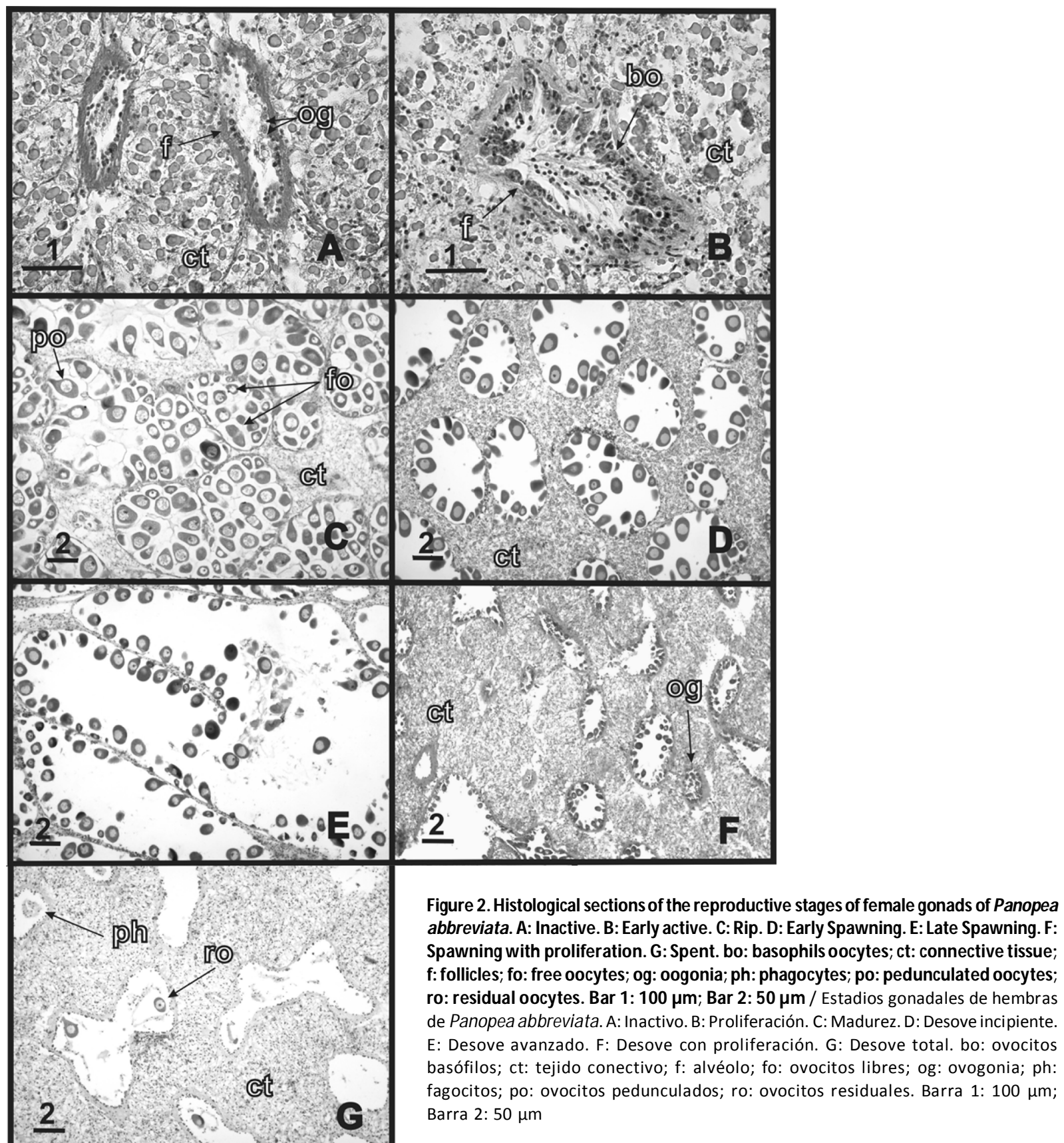



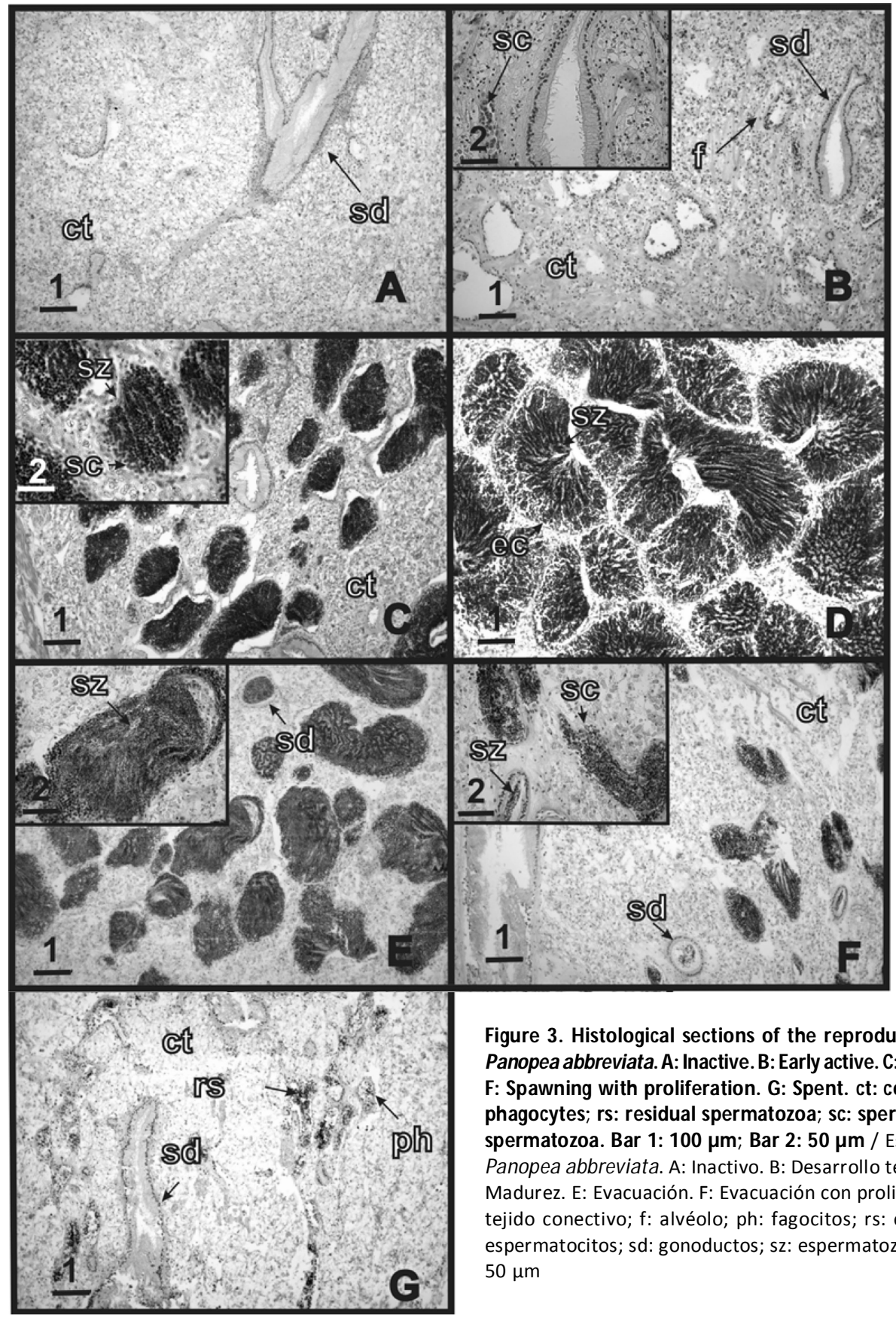

Figure 3. Histological sections of the reproductive stages of male gonads of Panopea abbreviata. A: Inactive. B: Early active. C: Late active. D: Ripe. E: Spawning. F: Spawning with proliferation. G: Spent. ct: connective tissue; f: follicles; ph: phagocytes; rs: residual spermatozoa; sc: spermatocytes; sd: sperm ducts; sz:

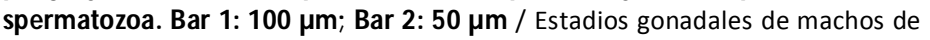
Panopea abbreviata. A: Inactivo. B: Desarrollo temprano. C: Desarrollo tardío. D: Madurez. E: Evacuación. F: Evacuación con proliferación. G: Evacuación total. ct: tejido conectivo; f: alvéolo; ph: fagocitos; rs: espermatozoides residuales; sc: espermatocitos; sd: gonoductos; sz: espermatozoides. Barra 1: $100 \mu \mathrm{m}$; Barra 2: $50 \mu \mathrm{m}$ 
Table 1. Histological features for the different stages of reproduction for Panopea abbreviata / Características histológicas de los diferentes estadios gonadales para Panopea abbreviata

\begin{tabular}{ll}
\hline \multicolumn{1}{c}{ Female } \\
\hline Inactive & $\begin{array}{l}\text { Presence of large amounts of connective tissue. } \\
\text { Some follicles with residual oocytes can be } \\
\text { observed. (Fig. 2A): }\end{array}$ \\
Early active & $\begin{array}{l}\text { Small follicles embedded in a large amount of } \\
\text { connective tissue. The follicles have relatively } \\
\text { thick walls. Oogonia are situated close to the } \\
\text { inner surface of the follicle wall and some small } \\
\text { and ovoid primary oocytes are interspersed } \\
\text { among the oogonia. (Fig. 2B). }\end{array}$
\end{tabular}

Late active among the oogonia. (Fig. 2B).

Male

Late active

Ripe

The connective tissue is scarce and only
observed in thin bands around the follicles. The follicles become larger and their walls are thinner. Occasionally, the wall between adjacent follicles is disrupted. When the primary oocytes are fully developed, they detach from the follicle walls and can be found free in the lumen. The primary oocytes increase in size and number, and their nuclei can contain more than one nucleolus (Fig. 2C).

Spawning Early Spawning: The number of oocytes found free in the lumen decrease. There are few pedunculated oocytes attached to the follicle walls. (Fig. 2D):

Late Spawning: Follicles decrease in size. Most of the remaining oocytes are detached from the follicle walls (Fig. 2E).

Spawning

with proliferation

Spent
The follicles are almost empty with residual gametes, however, there are many oogonia attached to the follicle walls (Fig. 2F).

The spent gonad is small with empty follicles surrounded by large amounts of connective tissue, although some contain residual primary oocytes. Abundant phagocytes are present in the follicles and connective tissue. (Fig. 2G).
Through this stage, the amount of connective tissue diminishes and the follicles increase in size and number. The follicles are almost filled, with an increasing number of spermatocytes (highly eosinophilic, rounded cells, smaller than the spermatogonia,) situated in the center and of the follicle surrounded by spermatogonia.. In some follicles, spermatozoa can be distinguished (Fig. 3C).

Ripe gonads consist of big, full follicles separated by thin bands of connective tissue. All stages of spermatogenesis are present. Spermatozoa are the most numerous cells in the follicles. They are basophilic, elongated and slender. Their heads are packed closely together and their eosinophilic tails are directed towards the center of the lumen. The ripe follicles are clustered and converge into the sperm ducts, which often contain spermatozoa. (Fig. 3D).

The beginning of spawning is marked by the appearance of less dense follicles and sperm-filled ducts. Moreover, the array of spermatozoa inside the follicle is less ordered (Fig. 3E).

The follicles are almost empty with residual gametes. There are numerous spermatogonia attached to the follicle walls. (Fig. 3F).

The follicles are almost totally collapsed, contain few spermatozoa, and some are empty. The sperm ducts are often distended and connective tissue occupies most of the gonad. At the end of this stage, numerous phagocytes can be distinguished within the follicles and connective tissue (Fig. 3G). 


\section{QUANTITATIVE INDICATORS}

Quantitative information was analyzed to assist with the interpretation of the temporal reproductive pattern. At monthly intervals frequency distributions of oocyte diameters (ODFD) were estimated. Oocytes were measured at 400x magnification, with an ocular micrometer. Under the assumption that the nucleolus is located in the center of each oocyte, only cells showing the nucleolus were measured. The relative oocyte area ROA (area of all oocytes present in any ocular field as a percentage of the field area) was estimated for each sample as follows: (1) mean number of oocytes per field was calculated based on the observation of three fields for each of five randomly selected individuals; (2) oocyte diameter $(d)$ classes from ODFD were converted to oocyte area assuming sphericity $\left(\operatorname{area}=\pi(d / 2)^{2}\right)$, multiplied by their respective frequencies, and integrated; (3) mean number of oocytes per field was multiplied by the ratio between the integrated oocyte area and the total frequency of oocytes in each ODFD. The resulting area was divided by the total area of a field $\left(0.089 \mathrm{~mm}^{2}\right)$ and multiplied by 100 .

Coefficients of variation for oocyte diameter and number of oocytes per field were obtained for each month and each locality. The coefficients of variation were compared between localities with ANOVA.

\section{RESULTS}

A total of 758 geoducks were processed, of which 422 $(55.67 \%)$ were male, $326(43.00 \%)$ were females, $6(0.79 \%)$ were sexually undifferentiated, and $4(0.53 \%)$ were hermaphrodite. Mean shell size was $93.84 \mathrm{~mm}(\mathrm{SD}=10.82$ $\mathrm{mm})$.

\section{Temperature}

In order to show the temporal variability of SST the monthly mean spatial values of SST were calculated for each of 3 sites. SST showed a clear seasonal cycle (Fig. 4); the annual cycle (Eq. 1) explained more than $99 \%$ of the variance (Table 2). In this case, the change of phase corresponded to the moment of the year when SST was highest, at the beginning of February $\left(\mathrm{t}_{0}=2.07,21.5^{\circ} \mathrm{C}\right)$ in El Sotano, around mid-February in Puerto Lobos $\left(\mathrm{t}_{0}=2.27,19.9^{\circ} \mathrm{C}\right)$ and the end of February in Punta Conos $\left(\mathrm{t}_{0}=2.72,18.2^{\circ} \mathrm{C}\right)$. Surface water was warmest in $\mathrm{El}$ Sotano and Puerto Lobos, and colder in Punta Conos (Table 3). Punta Conos and El Sotano showed the lowest and the highest thermal amplitudes, respectively $\left(3.80,4.8^{\circ} \mathrm{C}\right)$. Lowest mean and minimum SST corresponded to Punta Conos (Fig. 4).
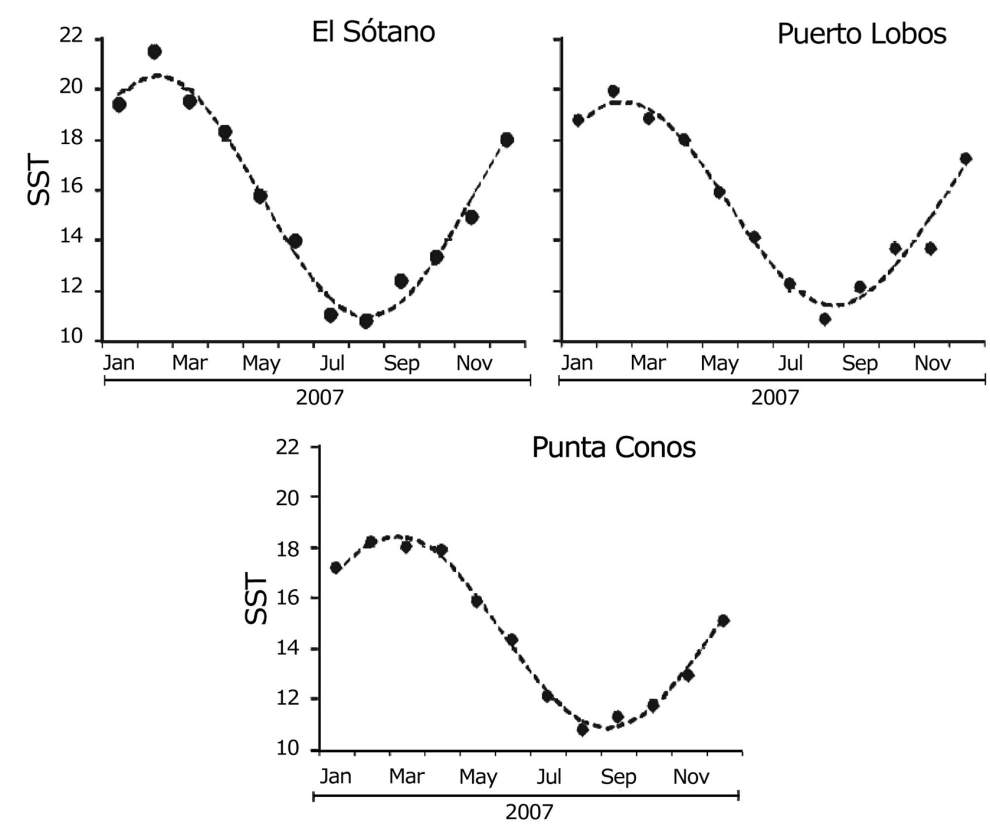

Figure 4. Variation of SST for El Sótano, Puerto Lobos and Punta Conos throughout 2007. Line: model; full circle: monthly mean / Variación anual de la SST para El Sótano, Puerto Lobos y Punta Conos durante 2007. Línea: modelo; círculo: promedios mensuales 
Table 2. Parameters of SST model (Eq 1) discriminated by location: mean temporal value $\left(T_{0}\right)$, annual harmonic amplitude $\left(T_{1}\right)$, annual harmonic phase $\left(\mathbf{t}_{0}\right)$, correlation coefficient $\left(\mathbf{r}^{2}\right)$, standard deviation (SD) / Parámetros del modelo de SST (Eq 1) discriminado por sitio: promedio mensual temporal $\left(T_{0}\right)$, amplitud armónica anual $\left(T_{1}\right)$, fase armónica anual $\left(t_{0}\right)$, coeficiente de correlación $\left(r^{2}\right)$, desviación estándar (SD)

\begin{tabular}{lccccccc}
\hline Site & $\mathrm{T}_{0}\left({ }^{\circ} \mathrm{C}\right)$ & $\mathrm{T}_{1}\left({ }^{\circ} \mathrm{C}\right)$ & $\mathrm{t}_{0}$ & $\mathrm{r}^{2}$ & $\operatorname{Min}\left({ }^{\circ} \mathrm{C}\right)$ & $\operatorname{Max}\left({ }^{\circ} \mathrm{C}\right)$ & $\mathrm{SD}$ \\
\hline El Sótano & 15.73 & 4.79 & 2.07 & 0.99 & 10.74 & 21.50 & 3.58 \\
Puerto Lobos & 15.43 & 4.07 & 2.27 & 0.99 & 10.87 & 19.91 & 3.05 \\
Punta Conos & 14.64 & 3.80 & 2.72 & 1.00 & 10.80 & 18.24 & 2.82 \\
\hline
\end{tabular}

Table 3. Statistic results of comparison between in situ temperature and MCSST algorithm for the El Sótano: mean difference (MD), the standard deviation of the mean difference (SD) and the root mean square error (RM SE) between the algorithm-derived and the temperature in situ SST / Resultados estadísticos de la comparación entre la temperatura in situ y MCSST algoritmo para El Sótano: diferencia media (MD), la desviación estándar de la diferencia media (SD) y raíz del cuadrado del error promedio (RMSE) entre el algoritmo y la temperatura SST medida in situ

\begin{tabular}{lllllllll}
\hline slope & {$[\text { slope }]_{95 \%}$} & intercept & {$[\text { intercept }]_{95 \%}$} & $\mathrm{r}^{2}$ & MD & SD & RMSE & $\mathrm{n}$ \\
\hline 1.27 & {$[1.20-1.35]$} & -2.17 & {$[-3.26-1.08]$} & 0.81 & 1.98 & 1.58 & 2.53 & 246 \\
\hline
\end{tabular}
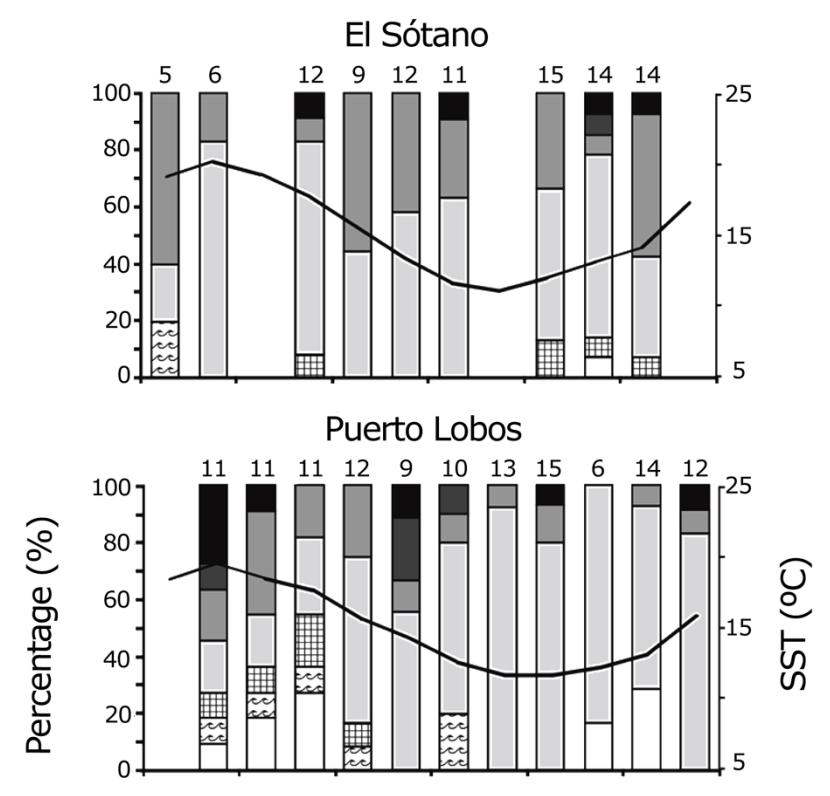

Punta Conos

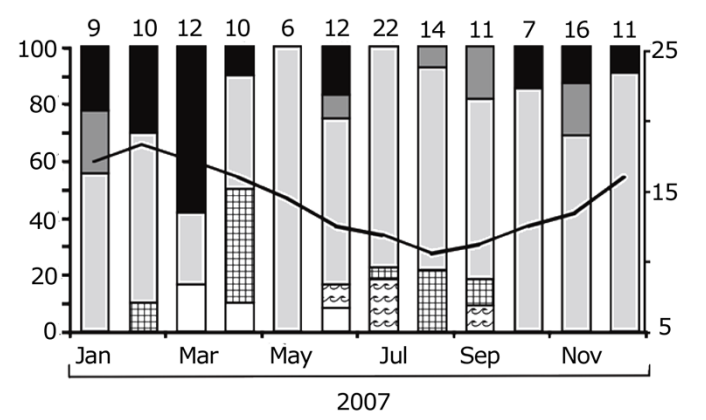

$\square$ I 四II 曲 III $\square$ IV $\square$ V $\square$ VI $\square$ VII
Figure 5. Proportional bar chart of the histological data showing the reproductive cycle of female Panopea abbreviata and SST cycle (line). The number above each bar indicated the number total of females observed. I: Inactive, II: Early active, III: Ripe; IV: Early Spawning, V: Late Spawning, VI: Spawning with proliferation, VII: Spent / Proporción de los estadios gonadales de las hembras de Panopea abbreviata y ciclo de SST (línea). Arriba de cada columna se indica el número de hembras observadas. I: Inactivo, II: Proliferación, III: Madurez, IV: Desove incipiente, V: Desove avanzado, VI: Desove con proliferación, VII: Desove total 


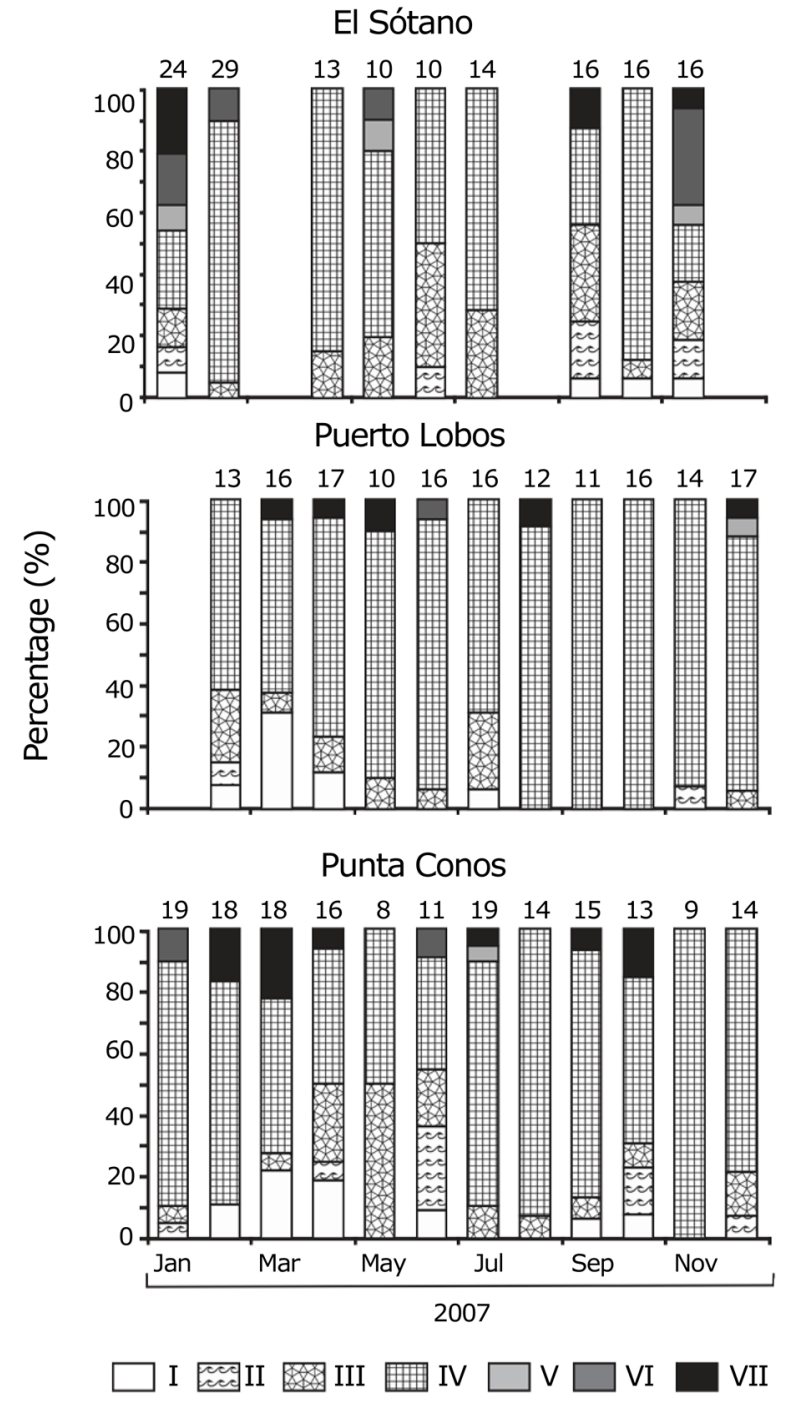

Figure 6. Proportional bar chart of the histological data showing the reproductive cycle of male Panopea abbreviata. The number above each bar indicated the number total of females observed. I: Inactive, II: Early active, III: Late active, IV: Ripe, V: Spawning, VI: Spawning with proliferation, VII: Spent / Proporción de los estadios gonadales de los machos de Panopea abbreviata. Arriba de cada columna se indica el número de machos. I: Inactivo, II: Desarrollo temprano, III: Desarrollo tardío, IV: Madurez, V: Evacuación, VI: Evacuación con proliferación, VII: Evacuación total
The total number of in situ data points collected on El Sótano was 355. Due to cloud cover and after applying the temporal selections criteria, the match-up was reduced to 249 data points. These data covered a range of $i n$ situ temperature from 10.22$20.19^{\circ} \mathrm{C}$.

Match-up results demonstrated a good fit $\left(r^{2}>0.80\right)$ and statistical significance $(P<0.05)$, however the mean difference and slope of the SMA model indicated an overestimation of the MCSST algorithm in relation to in situ records (Table 2).

\section{REPRODUCTIVE CYCLE}

In all studied populations, mature individuals able to spawning were present throughout the entire study, without a resting period during the reproductive cycle. Most of the females were observed in different spawning stages (early spawning, late spawning, spent and spawning with proliferation) during the study period (Fig. 5). Most of the males were in ripe stage during the whole year. However, a slight seasonality in male cycle was observed at El Sótano, the late active stage was prevalent $(31.25 \%)$ in early spring (September), and spawning with proliferation stage was prevalent $(31.25 \%)$ in late spring (November) (Fig. 6). During the whole year, females and males are spawning.

The frequency distribution of oocyte diameter showed an heterogeneous pattern with most oocyte stages present (oogonia, oocytes pedunculated and oocytes free). Throughout the year, in all the localities, ranged between 3 and $46.5 \mu \mathrm{m}$ at El Sótano, 3 and $60 \mu \mathrm{m}$ at Puerto Lobos, and 3 and $70.5 \mu \mathrm{m}$ at Punta Conos (Fig. 7). Mean oocyte diameter showed no clear trend throughout the study period (Fig. 8). Coefficients of variation for oocyte diameter varied between 20-46\%. Coefficients of variation for oocyte diameter differed significantly among sites (ANOVA, $P$ $<<0.01)$. Variation was greatest at El Sótano $(\overline{\mathrm{x}}=0.41)$, less at Puerto Lobos $(\overline{\mathrm{x}}=0.32)$ and intermediate at Punta Conos $(\bar{x}=0.36)$.

Mean number of oocytes per field showed peaks throughout the year at all localities (Fig. 8). However, the numbers of oocytes per field showed variation, that was: the greatest at $\mathrm{El}$ Sótano ( $\bar{x}=0.59)$, the least at Puerto Lobos $(\bar{x}=0.38)$ and intermediate at Punta Conos ( $\overline{\mathrm{x}}=0.49)$. Coefficients of variation for number of oocytes per field varied between 19 and 71\% and differed significantly among sites (ANOVA, $P=0.006$ ).

Temporal pattern of relative oocyte area (ROA) was the result of the associated effect of the mean number of oocytes per field and the proliferation, maturation and spawning cycle events. The ROA index showed a peak in May (mid-autumn) 


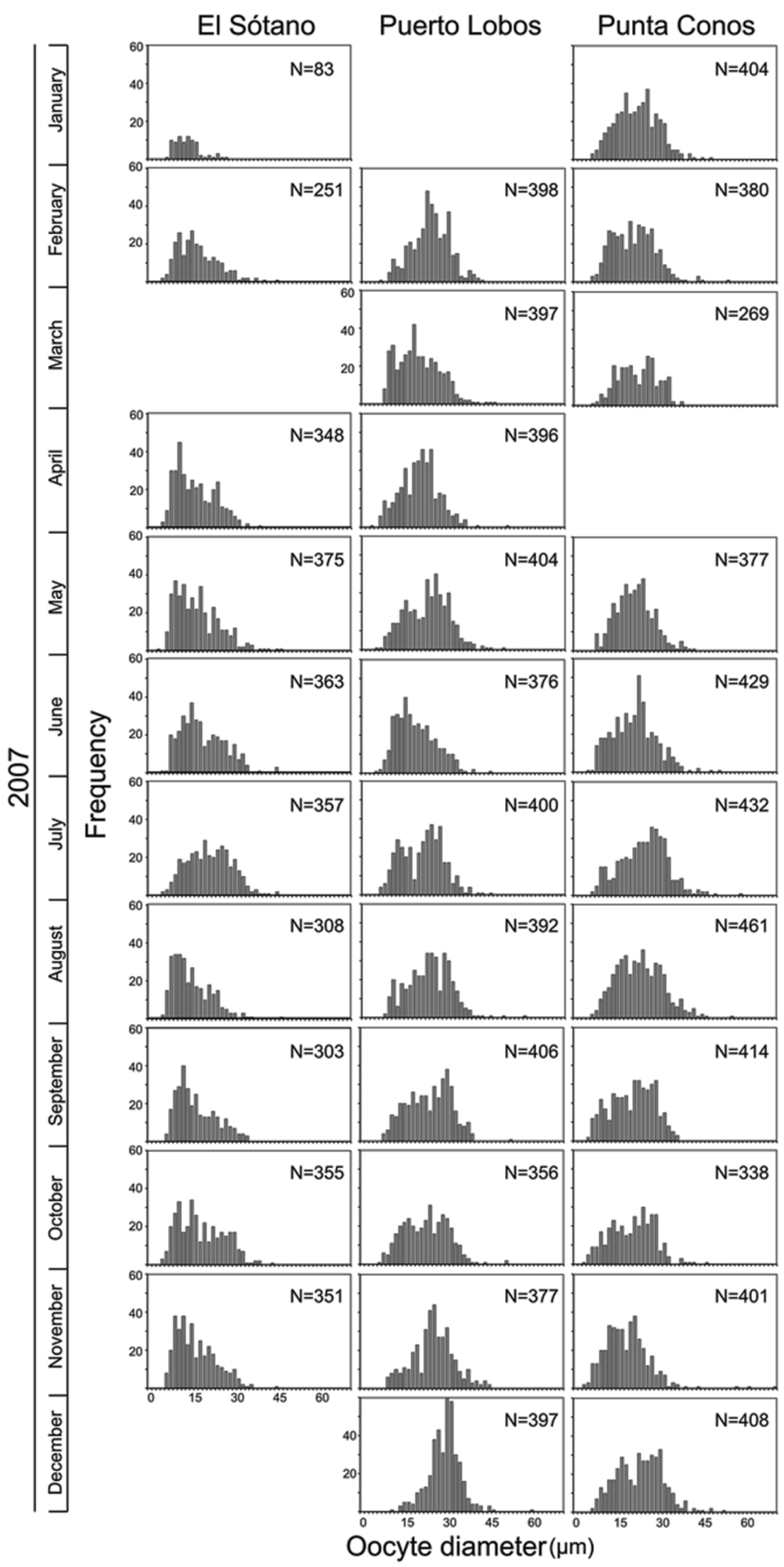

Figure 7. Monthly oocyte diameter distribution of Panopea abbreviata for El Sótano, Puerto Lobos and Punta Conos, throughout 2007 / Frecuencias de diámetros ovocitarios de Panopea abbreviata en el El Sótano, Puerto Lobos y Punta Conos, para el 2007 
at all localities, in San Matias Gulf localities increase one more time until the end of the year, while at Punta Conos, there were several peaks throughout the year (Fig. 8). The decreasing trend in the ROA index at El Sótano and Puerto Lobos was similar during winter and spring, suggesting that spawning was more pronounced in these localities. In contrast, during summer and autumn an increasing trend in the ROA was observed, suggesting that proliferation phase prevailed over spawning. On the other hand, the trend in the ROA index at Punta Conos showed several changes throughout the year, suggesting that the cycle of the predominance of one particular stage over the other, was shorter than those observed in the other two localities.

\section{Discussion}

We found slight variation in the reproductive cycle of $P$. abbreviata between the 3 localities on the northern Patagonian coast. This variation was observed only when we compared quantitative indicators for females. These indicators showed similar slight seasonality in the reproductive pattern at Puerto Lobos and El Sótano, while at Punta Conos was more irregular. For both sexes, at all localities, there was no reproductive quiescent period. These results are consistent with those reported for other populations of $P$. abbreviata (Van der Molen et al. 2007). The clams of the genus Panopea have geographical ranges that typically vary significantly in annual temperature regime. With the exception of $P$. abbreviata, all other species of the genus have a well-defined annual cycle of gametogenesis with a period of reproductive inactivity (Sloan \& Robinson 1984, Gribben et al. 2004, Calderón-Aguilera et al. 2008).

The control of reproduction, in marine bivalves, involves the complex interplay of exogenous factors such as temperature, food, salinity and light, with endogenous factors such as neuroendocrine cycles and genotype. Between the external factors, temperature has been documented as a main factor that control the reproductive processes, as the initiation of the reproductive cycle, the maturation of germ cells and spawning (Giese 1959, Ruiz et al. 1992, Fabioux et al. 2005).

We found, in agreement with Smale \& Wernberg (2009), that SST were significantly correlated to the data logger collected at $\sim 10 \mathrm{~m}$ depth. However, satellite-derived temperatures tended to overestimate in situ derived temperature. All 3 studied sites have similar seasonal variation with a trend for mean temperature and seasonal amplitude in temperature decreasing with increasing latitude. In addition, the time of the maximum temperature was delayed with increasing latitude.
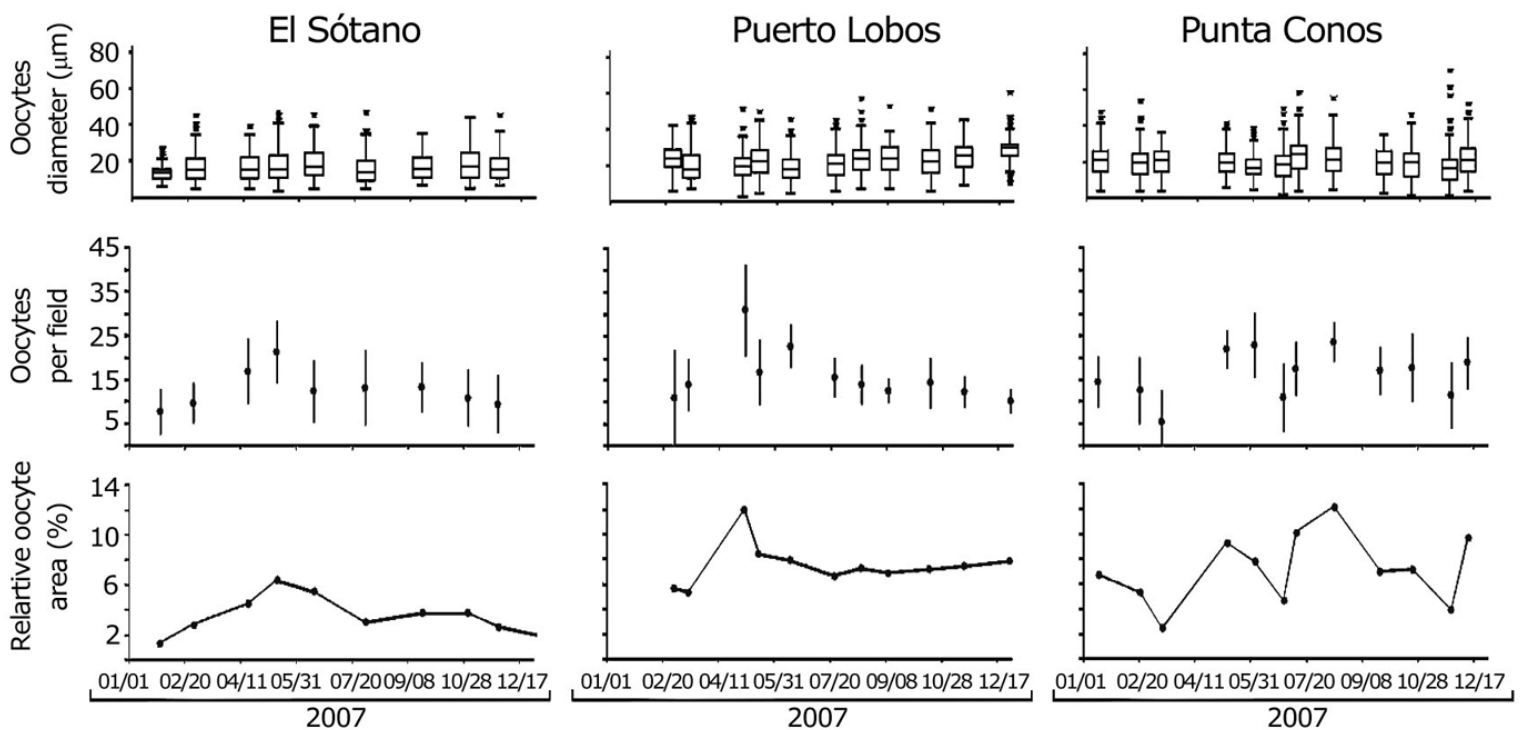

Figure 8. Quantitative indicators of female gonadal cycle of Panopea abbreviata for El Sótano, Puerto Lobos and Punta Conos throughout 2007 / Indicadores cuantitativos del ciclo gonadal de las hembras de Panopea abbreviata para El Sótano, Puerto Lobos y Punta Conos durante 2007 
The female clams from El Sótano and Puerto Lobos showed similar seasonality in the reproductive pattern. Proliferation and maturation phases prevailed over spawning stages when temperature decreased during autumn (March-May). This pattern was reversed when temperatures began to increase during spring (September-November). At Punta Conos this pattern is more irregular suggesting that the seasonal temperature changes do not have effects in the reproductive pattern. Although, we observed slight seasonality in quantitative indicators, these had great variability at the same period and site. Moreover, for all localities both sexes had a continuous gamete proliferation and spawning throughout the year. These results suggest that seasonal variations in temperature only regulate slightly the annual cycle of gametogenesis for $P$. abbreviata. The same could happen with other oceanographic variables that have seasonal variations, such as photoperiod and primary productivity (Williams et al. 2013).

The reproductive pattern of many bivalves in the SW Atlantic Ocean is characterized by multiple spawning pulses, where only a part of gonadic stock is involved, and followed by rapid gonadal recovery (Calvo et al. 1998). Asynchronous and repetitive pulses of reproductive activity may result in an increased reproductive success. The longest time in which there are larvae present in the environment allow avoid extrinsic causes of mortality, which do not operate uniformly over time (Newell et al. 1982, Joaquim et al. 2014). However, we found a slight seasonality for the reproductive pattern of $P$. abbreviata that could be interpreted within this pattern, with many small pulses in reproductive activity that are difficult to detect and characterized by year-round spawning. This pattern is similar in the 3 sites.

\section{ACKNOWLEDGEMENTS}

The authors would like to thank the Argentine Comision Nacional de Actividades Espaciales (CONAE) for the AVHRRNOAA $11 \mathrm{~b}$ images provided. The authors thank diving staff of CENPAT and IBMPAS for diving assistance and Ayelén Fernández for collaboration in the English translation. This work was supported by the Consejo Nacional de Investigaciones Científicas y Técnicas (CONICET), the Agencia Nacional de Promoción Científica y Tecnológica (ANPCyT) (PID 2003371 and PICT $\left.2003 \mathrm{~N}^{\circ} 15221,2006 \mathrm{~N}^{\circ} 1575,2006 \mathrm{~N}^{\circ} 649\right)$ and by the PNUD ARG 02/018 - GEF No. 28.385.

\section{LITERATURE CITED}

Ageitos de Castellanos ZJ. 1967. Catálogo de los moluscos marinos bonaerenses, 365 pp. CIC, La Plata.
Calderón-Aguilera LE, AE Romo-Curiel, VM Moreno, J Cruz \& Y Guerrero-Rentería. 2008. Aspectos preliminares de la pesquería de almeja generosa en la cosa de Baja California. Memorias del IV Foro Científico de Pesca Ribereña, 09 al 11 de septiembre de 2008, Acapulco, pp. 6162.

Calderón-Aguilera LE, EA Aragón-Noriega, H ReyesBonilla, CG Paniagua-Chávez, AE Romo-Curiel \& VM Moreno-Rivera. 2010. Reproduction of the Cortes geoduck Panopea globosa (Bivalvia: Hiatellidae) and its relationship with temperature and ocean productivity. Journal of Shellfish Research 29(1): 135-141.

Calvo J, E Morriconi \& PM Orler. 1998. Estrategias reproductivas de moluscos bivalvos y equinoideos. In: Boschi EE (ed). El mar Argentino y sus recursos pesqueros, pp. 195-231. INIDEP, Mar del Plata.

Eversole AG. 1989. Gametogenesis and spawning in North American clam populations: implications for culture. In: Manzi JJ \& M Castagna (eds). Developments in Aquaculture and Fisheries Science, Clam Mariculture in North America 19: 75-109. Elsevier, Amsterdam.

Fabioux C, A Huvet, P Le Souchu, M Le Pennec \& S Pouvreau. 2005. Temperature and photoperiod drive Crassostrea gigas reproductive internal clock. Aquaculture 250(1): 458-470.

Freites L, L Montero, D Arrieche, JMF Babarro, PE Saucedo, C Córdova \& N García. 2010. Influence of environmental factors on the reproductive cycle of the eared ark Anadara notabilis (Röding, 1798) in Northeastern Venezuela. Journal of Shellfish Research 29(1): 69-75.

Giese AC. 1959. Comparative physiology: annual reproductive cycles of marine invertebrates. Annual Review of Physiology 21(1): 547-576.

Gosling E. 2003. Bivalve molluscs, biology, ecology and culture, 439 pp. Wiley, Oxford.

Gribben PE, J Helson \& AG Jeffs. 2004. Reproductive cycle of the New Zealand geoduck, Panopea zelandica, in two North Island populations. The Veliger 47(1): 59-71.

Hooker SH \& RG Creese. 1995. The reproductive biology of Pipi, Paphies australis (Gmelin, 1790) (Bivalvia: Mesodesmatidae). II. Spatial patterns of the reproductive cycle. Journal of Shellfish Research 14(1): 17-24.

Joaquim S, D Matias, AM Matias, P Moura, C Roque, L Chícharo \& MB Gaspar. 2014. Biochemical and energy dynamics throughout the reproductive cycle of the striped venus Chamelea gallina (Mollusca, Bivalvia). Invertebrate Reproduction and Development 58: 284-293.

Joll LM \& N Caputti. 1995. Geographic variation in the reproductive cycle of the saucer scallop, Amusium balloti (Bernardi, 1861) (Mollusca: Pectinidae), along the Western Australian Coast. Marine and Freshwater Research 46: 779792. 
Matias D, S Joaquim, AM Matias, P Moura, JT de Sousa, P Sobral \& A Leitão. 2013. The reproductive cycle of the European clam Ruditapes decussatus (L., 1758) in two Portuguese populations: Implications for management and aquaculture programs. Aquaculture 406: 52-61.

Morsan E, P Zaidman, RM Ocampo \& N Ciocco. 2010. Population structure, distribution and harvesting of southern geoduck, Panopea abbreviata, in San Matías Gulf (Patagonia, Argentina). Scientia Marina 74(4): 763-772.

Newell RIE, TJ Hilbish, RK Koehn \& CJ Newell. 1982. Temporal variation in the reproductive cycle of Mytilus edulis L. (Bivalvia, Mytilidae) from localities on the east coast of the Unites States. The Biological Bulletin 162: 299-310.

Olive PJ, C Lewis \& V Beardall. 2000. Fitness components of seasonal reproduction: an analysis using Nereis virens as a life history model. Oceanologica Acta 23(4): 377-389.

Olive PJW. 1994. Annual breeding cycles in marine invertebrates and enviromental temperature: probing the proximate and ultimate causes of reproductive synchrony. Journal of Thermal Biology 20 (1/2): 79-90.

Ruiz C, M Abad, F Sedano, L García-Martin \& J López. 1992. Influence of seasonal environmental changes on the gamete production and biochemical composition of Crassostrea gigas (Thunberg) in suspended culture in El Grove, Galicia, Spain. Journal of Experimental Marine Biology and Ecology 155(2): 249-262.
Sastry AN. 1977. Pelecypoda (excluding Ostreidae). In: Giese AC \& JS Pearse (eds). Reproduction of marine invertebrates, pp. 113-292. Academic Press, London.

Sloan NA \& SM Robinson. 1984. Age and gonad development in the geoduck clam Panopea abrupta (Conrad) from Southern British Columbia, Canada. Journal of Shellfish Research 4: 131-137.

Smale DA \& T Wernberg. 2009. Satellite-derived SST data as a proxy for water temperature in nearshore benthic ecology. Marine Ecology Progress Series 378: 27-37.

Van der Molen S, M Kroek \& N Ciocco. 2007. Reproductive cycle of the southern geoduck clam, Panopea abbreviata (Bivalvia: Hiatellidae), in north Patagonia, Argentina. Invertebrate Reproduction and Development 50(2): 75-84.

Williams GN, A Dogliotti, P Zaidman, M Solis, M Narvarte, R Gonzalez, J Esteves \& D Gagliardini. 2013. Assessment of remotely-sensed sea-surface temperature and chlorophyll- $a$ concentration in San Matías Gulf (Patagonia, Argentina). Continental Shelf Research 52: 159-171.

Zaidman P, M Kroeck, E Oehrens-Kissner \& E Morsan. 2012. Reproductive pattern of Southern geoduck, Panopea abbreviata, at El Sótano (San Matías Gulf, Patagonia, Argentina). Marine Biology Research 8: 172-181. 